\title{
Historical climate change and ocean turbulence as selective agents for two key phytoplankton functional groups
}

\author{
Sasha Tozzi ${ }^{1,2}$, Oscar Schofield ${ }^{1}$, Paul Falkowski ${ }^{1, *}$ \\ ${ }^{1}$ Environmental Biophysics and Molecular Ecology Program, Institute of Marine and Coastal Science, Rutgers University, \\ 71 Dudley Road, New Brunswick, New Jersey 08901, USA \\ ${ }^{2}$ Present address: Virginia Institute of Marine Science, The College of William and Mary, Gloucester Point, \\ Virginia 23062, USA
}

\begin{abstract}
Using a classical physiological model based on nutrient uptake kinetics, we explored the effect of turbulence on resource competition and succession between 2 phytoplankton functional groups on ecological and geological time scales. The 2 groups we considered are silica-precipitating diatoms and carbonate-precipitating coccolithophorids. Using published experimental laboratory data for parameterization, our model results suggest that diatoms dominate under highly turbulent regimes, while coccolithophorids tend to dominate under stable, nutrient-depleted conditions. We attribute the success of diatoms in highly dynamic systems to luxury uptake of nutrients afforded by the evolution of storage vacuoles. In contrast, coccolithophorids are more successful in resourcedepleted waters, due to their lower minimum limiting-nutrient requirement $\left(R^{*}\right)$. We examine how these differences in nutrient acquisition strategy potentially explain the long-term trends in the fortunes of these 2 taxa on geological time scales. The fossil record indicates that coccolithophorids rose to ecological prominence in the mid-Jurassic and reached an apex in the mid-Cretaceous, but have declined throughout the Cenozoic. In contrast, diatoms have risen rapidly in the late Cenozoic, especially from early-Miocene time to the present. Based on paleoclimate reconstructions, from Mesozoic times, we hypothesize that the relative success of the 2 functional groups reflects, in part, long-term changes in upper ocean turbulence and its influence on the temporal distribution of nutrients.
\end{abstract}

KEY WORDS: Coccolithophorid $\cdot$ Diatom $\cdot$ Functional groups $\cdot$ Phytoplankton $\cdot$ Turbulence $\cdot$ Vacuole Resale or republication not permitted without written consent of the publisher

\section{INTRODUCTION}

The cascade of turbulent energy in the upper ocean creates a continuously fluctuating environment on scales from hundreds of kilometers to millimeters (Kolmogorov 1941, Denman \& Gargett 1983). On scales relevant to individual phytoplankton cells (Estrada \& Berdalet 1997), these fluctuations preclude equilibrium conditions, such that multiple species from diverse taxa co-exist within the same water mass (Hutchinson 1961, Siegel 1998, Li 2002). However, given a finite number of nutritional elements and a single energy source, phytoplankton inevitably com- pete for resources (Tilman 1977). Consequently, selection imposed by resource competition has led to taxa level physiological diversification. In this paper, we explore how trade-offs of these adaptations, such as the evolution of a storage vacuole and higher nutrient uptake affinity, can confer selection pressure on phytoplankton community structure on geological and ecological scales.

We consider competition between 2 phytoplankton organisms representing 2 functional groups (IglesiasRodriguez et al. 2002). One group has a storage vacuole and can accumulate nutrients in excess of its immediate growth requirements (Raven 1997). We 
assume, for the sake of simplicity, that the second group has no nutrient storage capability. This is analogous to the competition between diatoms (Bacillariophyceae) and coccolithophorids (Primnesiophyceae), 2 classes that greatly influence biogeochemical cycles in the modern ocean (Iglesias-Rodriguez et al. 2002), and have left strong geological imprints in the sedimentary record for the past 200 million yr (Myr). For our modeling exercise, we simplified the complexity and diversity found in nature and we did not focus on any specific diatom and coccolithophorid body form. We assumed both cells are of equal size, thereby eliminating allometric effects while simultaneously concentrating on the effect of nutrient acquisition strategies vacuoles potentially confer. While allometric effects can be significant, and the size structure of the 2 functional groups has changed on geological time scales (Finkel et al. unpubl.), allometry per se cannot explain competitive selection on geological time scales because of adaptive evolution (Cohen et al. 1993).

The fossil record indicates that coccolithophorids originated in mid-Triassic times and reached a maximum in species richness in the Cretaceous (Roth 1987, Bown et al. 1992). On ecological time scales, formation of precipitation of calcite by coccolithophorids (Young et al. 1991) alters the equilibrium of the inorganic carbon system and alkalinity of seawater (Holligan \& Robertson 1996). On geological time scales, the calcite contributes to the formation of massive sedimentary rocks, which is the major sink for mobile carbon on Earth (Falkowski \& Raven 1997). The origin of diatoms is more ambiguous; however, the first verifiable fossils are recorded in mid-Jurassic times (Harwood \& Nikolaev 1995), but the fossil record suggests the group did not have much of an ecological impact in Mesozoic time. By the middle of the Cenozoic, however, especially at the Eocene-Oligocene boundary, diatoms became a widely diverse group that has steadily risen to ecological prominence to the present time (Falkowski et al. 2004). Indeed, in the modern ocean, diatoms are among the most successful eukaryotic phytoplankton, contributing as much as $40 \%$ of global oceanic net primary production and a proportionately high fraction of the organic carbon exported to the ocean interior (Longhurst \& Harrison 1989, Smetacek 1999).

Competition between these 2 taxa can be inferred in the contemporary ocean based on observations of living cells, and can be extended to geological time scales based on the fossil record. Our central hypothesis is that nutrient pulses, with different frequencies and intensity, regulate the abundance, dominance, and succession of coccolithophorids and diatoms. This hypothesis is a corollary of both the intermediate disturbance hypothesis (Connell 1978), and the physical disturbance hypothesis (Margalef 1978, Sousa 1979a,b, Lewis et al. 1984, Margalef 1997). Species diversity is greatest with 'intermediate' amounts of disturbance, i.e. the physical dynamics neither reflect the lowest nor highest free energy states. The size and intensity of the disturbances also determines diversity (Connell 1978, Sommer 1985). These basic concepts have been broadly applied in marine plankton ecology to explore community dynamics and diversity. Here we examine the hypothesis in the context of a classical model based on resource competition for nutrients (Tilman 1977) on geological time scales.

\section{THE COMPETITION MODEL}

Competition was numerically simulated using a modified version of Droop's classical nutrient uptake model (Droop 1973). All symbols and constants are summarized in Table 1 . The model assumes that the phytoplankton is limited by only one resource required by both species, in this case $\mathrm{NO}^{3-}$. In the formulation the specific growth rate is $(\mu)$ of species (i) and can be related to the cell quota $(Q)$ for a nutrient $(R)$ :

$$
\mu_{i}=\mu_{\max , i} \cdot\left(\frac{Q_{i}-Q_{i}^{0}}{Q_{i}}\right)
$$

The growth rate $\left(\mu_{i}\right)$ reaches its maximum $\left(\mu_{\max , i}\right)$ and becomes asymptotic as $Q_{i}$ approaches $\infty$.

The rate of change of the population density $(N)$ is affected by the growth rate of the population and its mortality $\left(m_{i}\right)$ :

$$
\frac{\mathrm{d} N_{i}}{\mathrm{~d} t}=N_{i} \cdot\left(\mu_{i}-m_{i}\right)
$$

Nutrient uptake $\left(\rho_{i}\right)$ is a function of external nutrient concentration $(R)$, maximal uptake $\left(\rho_{\text {max }, i}\right)$ and half saturation constant $\left(K_{i}\right)$ and its dynamic is well described by a hyperbolic function:

$$
\rho_{i}=\frac{\rho_{\max , i} \cdot R}{K_{i}+R}
$$

The rate of change of the cell quota $\left(Q_{i}\right)$ is dependent upon the nutrient uptake rate $\left(\rho_{i}\right)$, maximal growth rate $\left(\mu_{\max , i}\right)$ and the difference between the instantaneous cell quota and the minimal cell quota $\left(Q_{i}{ }^{0}\right)$. The larger this difference, the slower is the rate of change of the cell quota:

$$
\frac{\mathrm{d} Q_{i}}{\mathrm{~d} t}=\rho-\mu_{\max , i} \cdot\left(Q_{i}-Q_{i}^{0}\right)
$$

The rate of change of the external nutrient concentration $(R)$ in the system is a function of the dilution rate $(D)$ and the total uptake by the organism:

$$
\frac{\mathrm{d} R}{\mathrm{~d} t}=D \cdot\left(R^{0}-R\right)-\sum N_{i} \cdot \rho_{i}
$$


Table 1. Symbols, their values, and the sources of data used in our model simulations of resource competition

\begin{tabular}{|c|c|c|c|c|}
\hline Symbol & Units & Meaning & Diatom & Coccolithophorid \\
\hline \multicolumn{5}{|c|}{ State variables: } \\
\hline$N$ & cell $1^{-1}$ & Population density & & \\
\hline$R$ & $\mu \mathrm{mol} \mathrm{l} \mathrm{l}^{-1}$ & External nutrient concentration & & \\
\hline$Q$ & $\mu \mathrm{mol} \mathrm{cell}{ }^{-1}$ & Cell quota & & \\
\hline \multicolumn{5}{|c|}{ Physiological functions: } \\
\hline$\rho$ & $\mu \mathrm{mol} \mathrm{cell}{ }^{-1} \mathrm{~d}^{-1}$ & Uptake rate & & \\
\hline \multicolumn{5}{|c|}{ Parameters: } \\
\hline$\rho_{\max }$ & $\mu \mathrm{mol} \mathrm{cell}{ }^{-1} \mathrm{~d}^{-1}$ & Maximal uptake rate & $1.5 \times 10^{-7} \mathrm{a}, \mathrm{b}, \mathrm{c}$ & $7.2 \times 10^{-8} \mathrm{~g}$ \\
\hline$\mu_{\max }$ & $\mathrm{d}^{-1}$ & Maximal growth rate & $2.00^{\mathrm{b}, \mathrm{d}, \mathrm{e}, \mathrm{f}}$ & $1.19^{\mathrm{d}, \mathrm{g}, \mathrm{h}}$ \\
\hline$Q^{0}$ & $\mu \mathrm{mol}$ cell $^{-1}$ & Minimal cell quota & $5.0 \times 10^{-8 ~ b}$ & $3.5 \times 10^{-8 \mathrm{f}}$ \\
\hline$K$ & $\mu \mathrm{mol} \mathrm{l} \mathrm{l}^{-1}$ & Half saturation constant for uptake & $0.50^{\mathrm{b}, \mathrm{f}}$ & $0.14^{\mathrm{a}, \mathrm{f}, \mathrm{i}}$ \\
\hline \multicolumn{5}{|c|}{ Notational conventions: } \\
\hline i & & \multicolumn{3}{|c|}{ Subscript to distinguish terms pertaining to a given species } \\
\hline$T$ & $\mathrm{~d}$ & \multicolumn{3}{|c|}{ Time } \\
\hline
\end{tabular}

This set of first order ordinary differential equations expresses the mass balance of the cell numbers and of the dissolved and cellular nutrient. This system of equations was solved numerically using the RungeKutta algorithm (Butcher 1987).

Intracellular storage capacity (e.g. a vacuole) introduces a time lag between the exhaustion of the extracellular nutrient concentration and the actual nutrient limitation of growth. As the extracellular pool becomes smaller, intracellular storage pools are reduced; however there will be a time delay between depletion of the extracellular pool of the limiting nutrient and the reduction in the rate of growth. This delay is a function of growth rate and buffers the cell from promptly responding to the external nutrient concentration. The buffering capacity declines as the cells divide without a sufficient supply of external nutrients to maintain balanced growth (sensu stricto, Falkowski \& Raven 1997).

When equilibrium is reached between loss and growth rates, the superior competitor will have a smaller resource requirement $\left(R_{i}^{*}\right)$ (Tilman 1977). The abstract parameter $R_{i}^{*}$ is described by Eq. (6.):

$$
R_{i}{ }^{*}=\frac{K_{i} \cdot \mu_{\max , i} \cdot m_{i}}{\rho_{\max , i} \cdot \mu_{\max , i}-\rho_{\max , i} \cdot m_{i}-\mu_{\max , i} \cdot Q_{i}^{0} \cdot m_{i}}
$$

This parameter can be used as a predictor of the competitive outcome at equilibrium and in the absence of competitors (Grover 1989). The prediction given by $\left(R^{\star}\right)$ may change if the system does not reach equilibrium, as in the case of a variable resource supply.
Parameterization of the model is based on a compilation of data obtained from published literature (Table 1). All runs were initialized with a density of 1000 cells for each species. The simulations were run for 8760 model hours, equivalent to $1 \mathrm{yr}$. The resource was supplied as a series of pulses at frequencies of 12, $4.8,1.85,1.0,0.33,0.2,0.13$ and 0.10 cycles $\mathrm{d}^{-1}$. These chosen frequencies are representative of a series of oceanographic mixing processes due to internal waves, semidiurnal and diurnal tides, and the average frequency of storm events in the ocean.

\section{MODEL RESULTS AND IMPLICATIONS}

While the numerical simulation model does not prove that turbulence per se is the key factor selecting between these 2 functional groups, the model does provide a useful heuristic framework in which to explore how nutrient uptake kinetics can interact with turbulence to influence the relative abundance of these 2 phytoplankton classes.

The results of the simulated competition between diatoms and coccolithophorids over a range of pulse frequencies and intensities for a year are presented in Fig. 1. As has been previously shown in similar model exercises (Sommer 1985, Grover 1991, Spijkerman \& Coesel 1996, Ducobu et al. 1998), the concentration of nutrients regulated the overall carrying capacity of the system. Our results suggest that the frequency of the nutrient pulses (i.e. a surrogate of turbulent mixing) was the key factor regulating the relative abundance of the 2 phytoplankton taxa. Diatoms were selected 

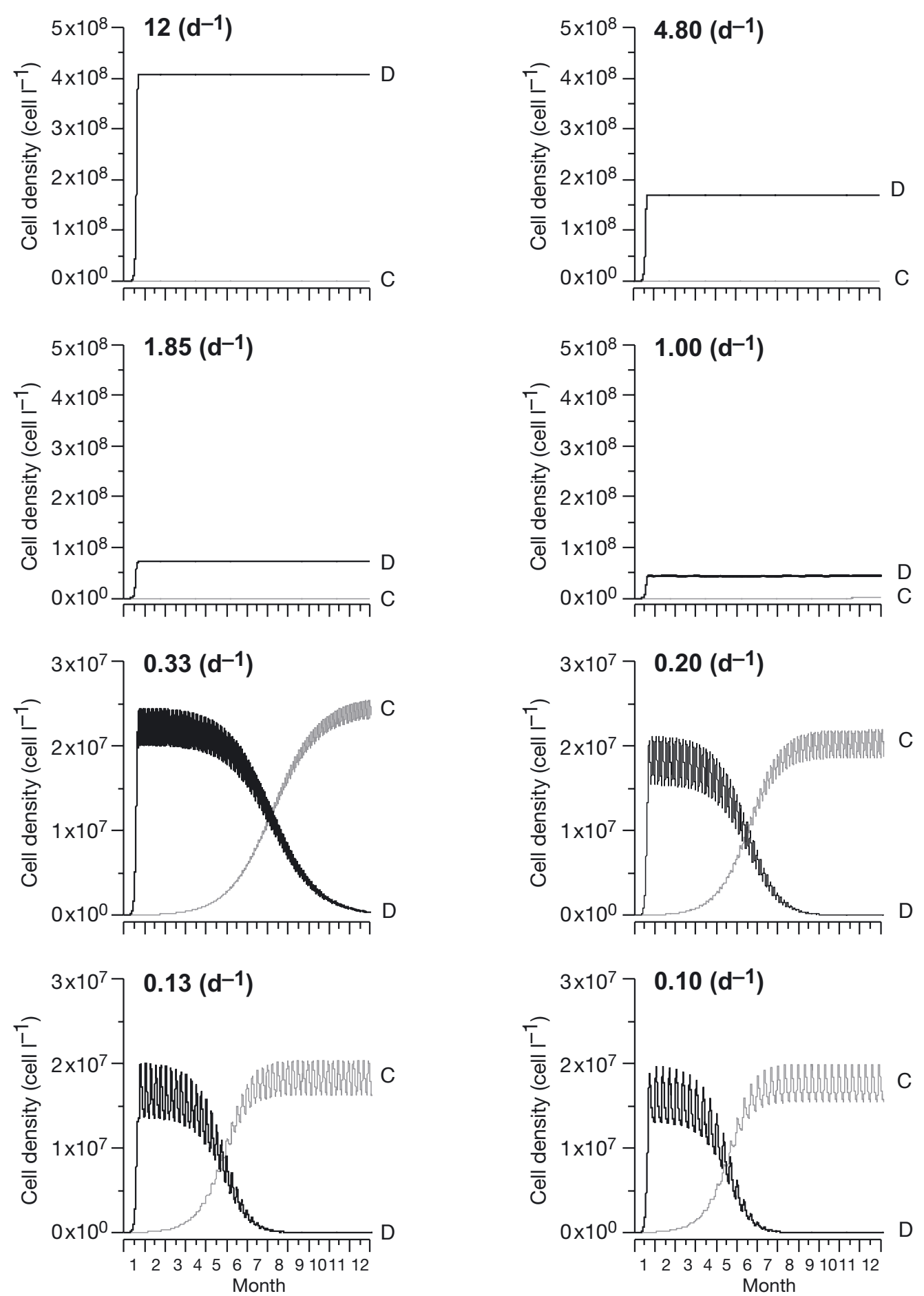

Fig. 1. Time course of competition between coccolithophorids (gray line, C) and diatoms (black line, D) under different disturbance periods. Disturbance frequencies were $12,4.8,1.85,1.0,0.33,0.2,0.13$ and 0.1 cycles d $^{-1}$

when the nutrient injections had a frequency of $0.40 \mathrm{~d}^{-1}$ or more, regardless of the concentration of nutrient within the pulse. The success of the diatoms at high pulse frequencies reflected their higher maximal growth rate due to higher maximal nutrient uptake rate and half saturation constants.
The presence of vacuoles in diatoms permits high growth rates as external nutrient concentrations decline (Fig. 2), thereby effectively extending the range of environmental conditions allowing for maximal diatom growth rates for at least 1 generation. This occurs as the rate of nutrient injection into the euphotic 

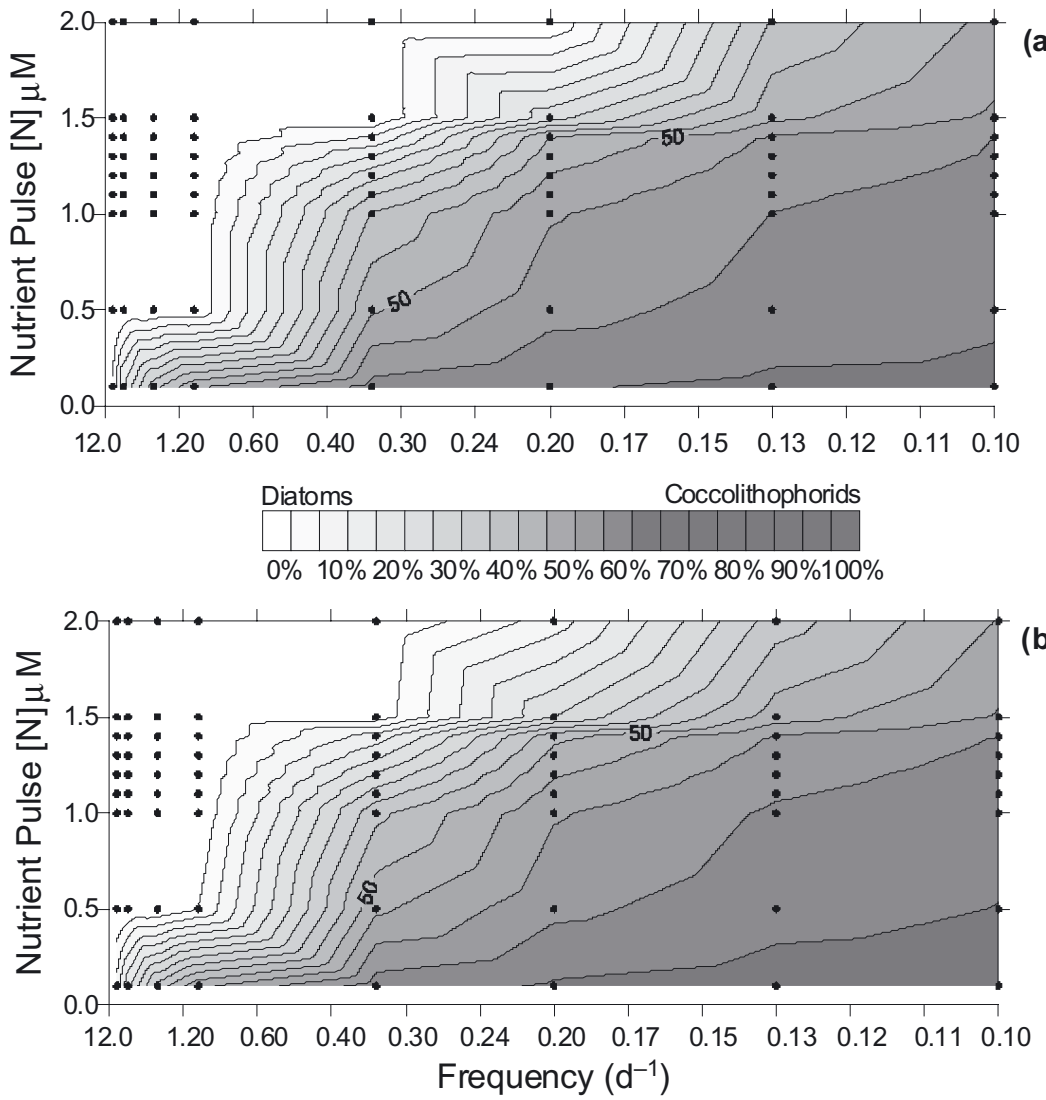

Fig. 2. Contour plots of the competition between diatoms and coccolithophorids. Nutrient pulse concentrations and pulse frequencies are indicated ( $\bullet$ ) for the different runs: (a) percentage of yearly persistence, (b) percentage of yearly biomass

zone is low. The ability to internally store nutrients was present in the cellular signature of the diatoms. The nitrogen cell quota for coccolithophorids never increased to more than $60 \%$ of the minimum. In contrast diatoms reached nitrogen cell quotas as high as $145 \%$. The increase in the cell quotas in the coccolithophorid is due only to an increase in cell size, while in diatoms the variation in cell quota reflects the combined effect of changes in cell size and nutrient storage. The variations in cell quota are due to the difference between $Q^{0}$ and the maximum cell quota $\left(Q_{\max }\right)$. The latter does not appear explicitly in our model formulation, but can be derived from Eq. (4) and will be defined by:

$$
Q_{\max }=\frac{\rho_{\max }}{\mu_{\max }}+Q^{0}
$$

Co-existence between diatoms and coccolithophorids over the simulated time was found at intermediate pulse frequencies between 0.48 and 0.20 cycles $\mathrm{d}^{-1}$. The co-existence was regulated by the frequency of the nutrient injections, the concentration of the nutrient injection modified the relative biomass between the taxa. Finally, nutrient pulses at frequencies of 0.20 cycles $\mathrm{d}^{-1}$ or less selected for coccolithophorids, regardless of the concentration of nutrient (Figs. $1 \& 2$ ). The success of the coccolithophorids under low frequency pulses reflected their lower $R^{*}$ values.

These model simulations qualitatively mimic field observations in the modern ocean. Diatoms are globally distributed and dominate phytoplankton community structure in nutrient-rich environments (Smetacek 1999). Given this, the lifetime of the diatom blooms has often been related to nutrient availability, which is driven by the overall mixing dynamics of the system (Margalef 1978, Legendre \& Fortin 1989, Thomas et al. 1997, Gibson 2000). In contrast, coccolithophorids have a higher affinity for nitrogen, which allows them to grow in low-nutrient environments, such as the Sargasso Sea, and to bloom in nutrient-depleted temperate seas (Hulburt 1970, Brown \& Yoder 1994, Balch et al. 1996, Henriksson 2000, Iglesias-Rodriguez et al. 2002). In the latter case, coccolithophorid blooms follow the bloom of diatoms earlier in the season (Iglesias-Rodriguez et al. 2002). These results can be related to the classic $r$ and $K$ paradigm (MacArthur \& Connel 1966), where $r$-strategists (e.g. diatoms) dominate in high mixing environments and $K$-strategists (e.g. coccolithophorids) dominate under oligotrophic conditions. Although competitive exclusion could theoretically occur under extreme conditions, and the model can force such a condition, this phenomenon does not occur in the real ocean. The coexistence, of 2 taxa competing for a single resource is a consequence of the dynamically unstable nature of aquatic ecosystems (Turpin \& Harrison 1979, Sommer 1984, Chesson \& Huntly 1997). However, there are trends in taxonomic dominance that are manifested on both ecological and geological time scales. This is an extension of Margalef's 'Mandala' in a geological context (Fig. 3).

The geological record during the Pleistocene reveals a periodicity of opal/calcite deposition corresponding to glacial/interglacial periods. We suggest that such alterations in mineral deposition are related to upper ocean turbulence linked to the Milankovitch cycle (Berger 1988), i.e. the sedimentary record is a 'fax machine' of mixing (Falkowski 2002). Glacial periods appear characterized by higher wind speeds and a stronger thermal contrast between the equator and 


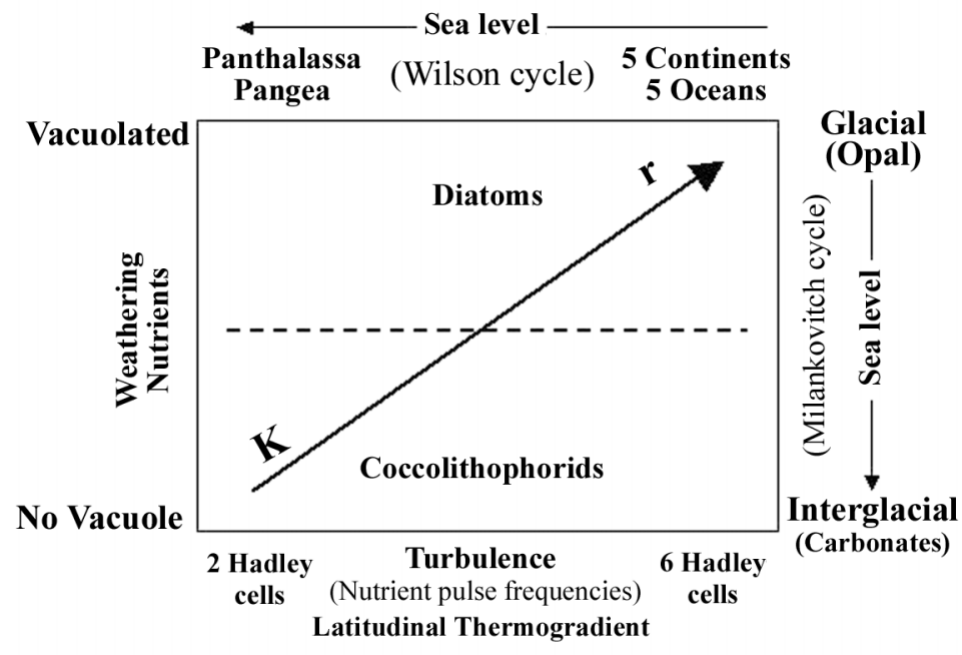

Fig. 3. Extension of Margalef's Mandala (Margalef 1997) to geological time scales, showing how changes in turbulence and nutrient availability can force a shift from $K$-strategist to $r$-strategist species. Turbulence and nutrient concentration in the ocean reflect the latitudinal thermal gradient that is a function of radiative forcing, continental configuration and sea level

pole. These 2 factors would, in accordance with our simple nutrient uptake model, favor diatoms over coccolithophorids (Gargett 1991). During an interglacial, more intense stratification, weaker winds, and a weaker thermal contrast between the equator and poles would tend to reduce upper ocean mixing and favor coccolithophorids. Silica and iron are not explicitly taken into account in our model, but these elements are mainly wind- and river-borne to the ocean, and their fluxes have been shown to be much higher during maximum glacial periods (Froelich et al. 1992, Harrison 2000) and therefore they co-occur with higher turbulence periods. Moreover, while silica availability will undoubtedly also influence the relative success of diatoms and coccolithophorids on these time scales, we suggest that the climatically forced cycle, played out on time scales of 100 kyr (kiloyears) (over the past $3 \mathrm{Myr}$ ), can be understood as a long-term competition that never reaches an exclusion equilibrium condition.

On longer time scales, however, the factors leading to the inverse dominance between coccolithophorids and diatoms are not clear. Over the past 65 Myr there has been a long-term trend in the diminution of coccolithophorids and a rise in the diversity of diatoms. Coccolithophorids emerged in the late Triassic and rapidly radiated throughout the Jurassic, reaching a zenith of species richness in the Cretaceous. At the Cretaceous-Tertiary $(\mathrm{K}-\mathrm{T})$ boundary, many species became extinct; moreover, throughout the Cenozoic, the number of species has declined (Roth 1987, Bown et al. 1992) (Fig. 4). The timing of the origin of diatoms is more elusive. The fossil record of diatoms in the Mesozoic is obscured by problems of preservation; however, several species are preserved in the late Jurassic (Harwood \& Nikolaev 1995), suggesting that the origins were in the early Jurassic or perhaps as early as the Triassic. It is clear, however, that this group did not contribute nearly as much to export production during Mesozoic times. Following the $\mathrm{K}-\mathrm{T}$ extinction event, however, diatoms became increasingly abundance and radiated rapidly in the Miocene. In the modern ocean, diatoms have become one of the dominant eukaryotic photosynthetic phytoplankton taxa (Smetacek 1999), disproportionately contributing to the export flux of organic carbon to the ocean interior (Longhurst \& Harrison 1989). What caused the changes in the fortunes of these 2 groups over the past $65 \mathrm{Myr}$ ?

We suggest that the ongoing successional displacement of coccolithophorids by diatoms in the Cenozoic is, to first order, driven by tectonic processes, especially the Wilson cycle (Worsley et al. 1986, Nance et al. 1988). The Mesozoic period was relatively warm and was characterized by a 2 cell Hadley circulation, with obliquity greater than $37.6^{\circ} \mathrm{C}$, resulting in a thoroughly mixed atmosphere with nearly uniform temperatures over the surface of the Earth. The atmospheric heat transport to high latitudes decreased the latitudinal thermogradients; global winds and ocean circulation were both sluggish (Huber et al. 1995). This relatively quiescent period of Earth's history was ideal for coccolithophorids. Following the $\mathrm{K}-\mathrm{T}$ bolide impact, and, more critically, after the onset of polar ice caps, about 32 Myr ago, the Hadley circulation changed dramatically (Crowley \& North 1991). The net result is more intense thermohaline circulation, greater wind speeds and decreased upper ocean stability (Chandler et al. 1992, Barron et al. 1995). These climatic changes, combined with orogenic events in the Cenozoic, resulted in an increase weathering and nutrient availability to the primary producers (Follmi 1996). Associated with the decrease in stability and increase in nutrient availability is the rise of the diatoms.

The early Cenozoic orogenic events, coupled with a decline in volcanism (Rampino \& Stothers 1988), led to a long-term depletion of $\mathrm{CO}_{2}$ and a corresponding decrease in temperature in the ocean interior resulting from global cooling. The resulting stratification has, in turn, led to an increased importance for wind-driven upwelling and mesoscale eddy turbulence in providing nutrients to the upper ocean (Bakun 1990). The ecological dominance of diatoms under sporadic mixing conditions suggests that their long-term success in the Cenozoic reflects an increase in event scale turbulent 


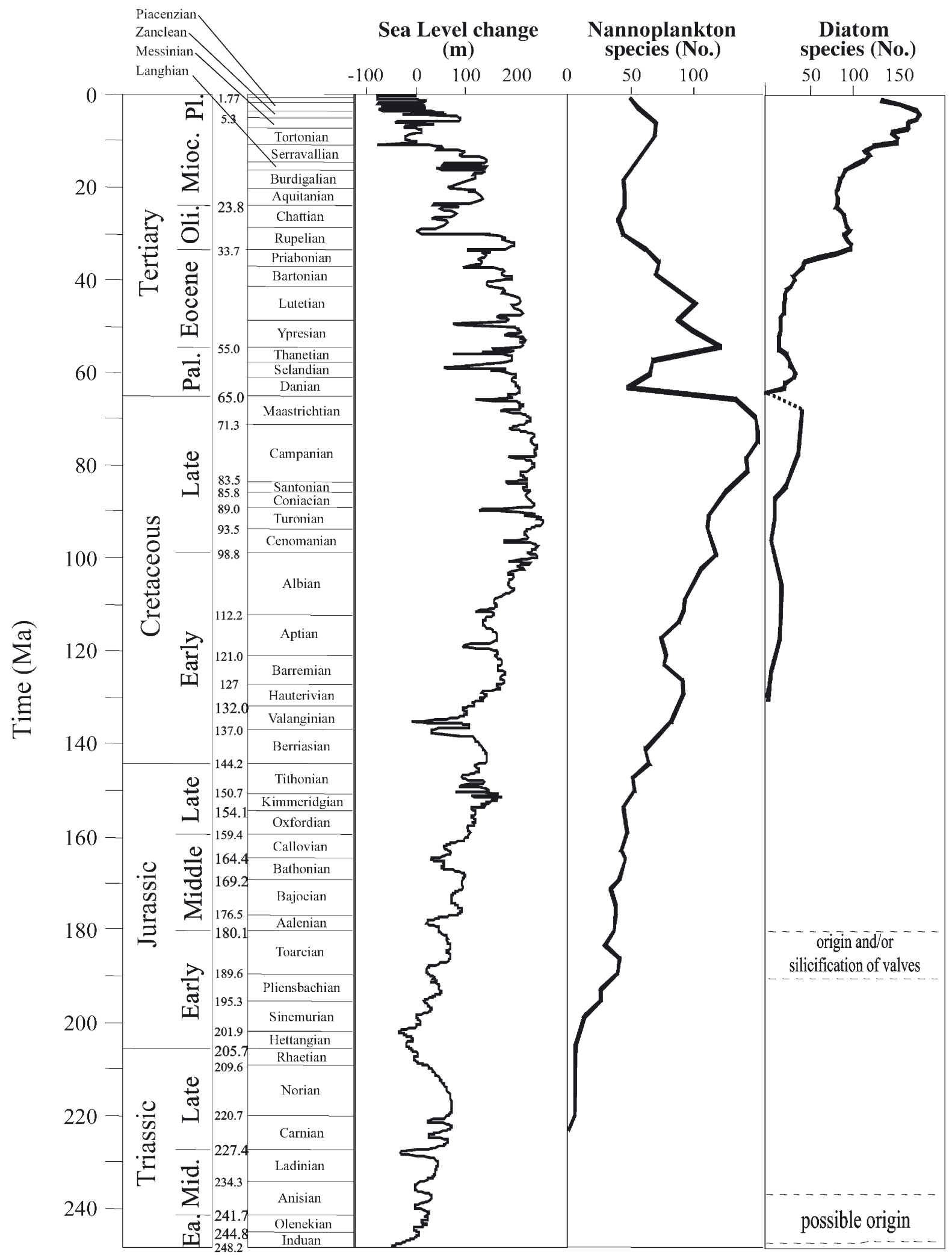

Fig. 4. Abundances of diatoms and coccolithophorids through Mesozoic and Cenozoic time. These estimates were based on Harwood \& Nikolaev (1995), Spencer-Cervato (1999), and Chacon-Baca et al. (2002). The sea level changes are based on Haq et al. (1987a,b, 1988). The data were kindly compiled by Katz (2004) and from Neptune-Database 2002. Ma: Million years ago; Pal.: Paleocene; Oli: Oligocene; Mioc.: Miocene; Pl.: Pleistocene 
energy dissipation in the upper ocean. Indeed, one could argue that the increase in diatom dominance, and the associated increase in the efficiency of carbon export from the upper ocean to the interior, may have played an important role in cooling the Earth throughout the Cenozic (Falkowski et al. 2004).

While the fossil records of phytoplankton are clearly incomplete, the macroevolutionary patterns of diatoms and calcareous nannoplankton over the past $250 \mathrm{Myr}$ clearly reflect ecological selection and physiological and structural adaptation. Our model results suggest that the evolution of a vacuole and the ensuing effect on nutrient uptake kinetics, is potentially an important determinant of diatom dominance in the contemporary ocean, and may have also played a major role in selecting for phytoplankton taxa on geological time scales. Clearly this was not, and should not be construed as the only adaptive process that determined the relative success of diatoms on geological time scales. The appropriation of a silica-based shell (i.e. frustule) clearly had adaptive advantages in relation to protection from some metazoan grazers (Hamm et al. 2003), and possibly viral infection (Smetacek 2001), as well as carbon acquisition (Milliagan \& Morel 2002), but also meant that diatoms had an absolute requirement for silicate, which can only be supplied by weathering of continental rocks (Falkowski et al. 2004). Plastid inheritance (Grzebyk et al. 2003), and trace element specificity (Quigg et al. 2003) were potentially additional selective agents that conferred an advantage to chromophyte organisms in general. It is clear, however, that our understanding of the factors controlling the tempo and mode of evolution of the major phytoplankton taxa are only poorly. We hope the hypothesis presented in this paper stimulates discussion of the critical processes and feedbacks between the evolution of these polyphyletic organisms and their role in shaping the geochemistry of the oceans for the past several hundred million years of Earth's history.

Acknowledgements. We thank E. Litchman, A. Irwin and E. Laws for help with modeling, M. Katz for discussions on the evolution of phytoplankton, and Victor Smetacek and John Raven for constructive comments to the manuscript. This research was supported by the U.S. National Science Foundation through a Biocomplexity grant (OCE 0084032), and by a graduate fellowship from Rutgers University to S.T.

\section{LITERATURE CITED}

Aksnes DL, Egge JK, Rosland R, Heimdal BR (1994) Representation of Emiliania huxleyi in simulation models. A first approach. SARSIA 79:291-300

Bakun A (1990) Global climate change and intensification of coastal ocean upwelling. Science 247:198-201

Balch WM, Kilpatrick KA, Trees CC (1996) The 1991 cocco- lithophore bloom in the central North Atlantic. 1. Optical properties and factors affecting their distribution. Limnol Oceanogr 41:1669-1683

Barron EJ, Fawcett PJ, Peterson WH, Pollard D, Thompson SL (1995) A simulation of Midcretaceous climate. Paleoceanography 10:953-962

Berger A (1988) Milankovitch theory and climate. Rev Geophys 26:624-657

Brown CW, Yoder JA (1994) Coccolithophorid blooms in the global ocean. J Geophys Res (Oceans) 99:7467-7482

Bown PR, Burnett JA, Gallagher LT (1992) Calcareous nannoplankton evolution. Mem Sci Geol 43:1-17

Butcher JC (1987) The numerical analysis of ordinary differential equations: Runge-Kutta and general linear methods. Academic Press, New York

Carpenter EJ, Guillard RRL (1971) Intraspecific differences in nitrate half-saturation constants for three species of marine phytoplankton. Ecology 52:183-185

Chacon-Baca E, Beraldi-Campesi H, Cevallos-Ferriz SRS, Knoll AH, Golubic S (2002) 70 Ma nonmarine diatoms from northern Mexico. Geology 30:279-281

Chandler MA, Rind D, Ruedy R (1992) Pangean climate during the Early Jurassic: GMC simulations and the sedimentary record of paleoclimate. Geol Soc Am Bull 104: 543-559

Chesson P, Huntly N (1997) The role of harsh and fluctuating conditions in the dynamics of ecological communities. Am Nat 150:519-553

Cohen JE, Pimm SL, Yodzis P, Saldana J (1993) Body sizes of animal predators and animal prey in food webs. J Anim Ecol 62:67-78

Connell JH (1978) Diversity in tropical rain forests and coral reefs. Science 199:1302-1310

Crowley T, North G (1991) Paleoclimatology. Oxford University Press, New York

Davidson K, Gurney WSC (1999) An investigation of nonsteady-state algal growth. II. Mathematical modelling of co-nutrient-limited algal growth. J Plankton Res 21: 839-858

Denman KL, Gargett AE (1983) Time and space scales of vertical mixing and advection of phytoplankton in the upper ocean. Limnol Oceanogr 28:801-815

Droop MR (1973) Some thoughts on nutrient limitation in algae. J Phycol 9:264-272

Ducobu H, Huisman J, Jonker RR, Mur LR (1998) Competition between a prochlorophyte and a cyanobacterium under various phosphorus regimes: comparison with the Droop model. J Phycol 34:467-476

Eppley RW, Rogers JN, McCarthy JJ (1969) Half-saturation constant for uptake of nitrate and ammonium by marine phytoplankton. Limnol Oceanogr 14:912-920

Estrada M, Berdalet E (1997) Phytoplankton in a turbulent world. Sci Mar 61:125-140

Falkowski PG (2002) The ocean's invisible forest-marine phytoplankton play a critical role in regulating the earth's climate. Could they also be used to combat global warming? Sci Am 287:54-61

Falkowski PG, Raven JA (1997) Aquatic photosynthesis. Blackwell, Malden, MA

Falkowski PG, Katz M, van Schootenbrugge B, Schofield O, Knoll AH (2004) Why is the land green and the ocean red? In: Thierstein HR (ed) Coccolithophores-from molecular processes to global impact. Springer-Verlag, Berlin

Fernández E, Fritzb JJ, Balch WM (1996) Chemical composition of the coccolithophorid Emiliania huxleyi under lightlimited steady state growth. J Exp Mar Biol Ecol 207: $149-160$ 
Follmi KB (1996) The phosphorus cycle, phosphogenesis and marine phosphate-rich deposits. Earth Sci Rev 40:55-124

Froelich PN, Blanc V, Mortlock RA, Chillrud SN, Dunstan W, Udomkit A, Peng TH (1992) River fluxes of dissolved silica to the ocean were higher during glacials: $\mathrm{Ge} / \mathrm{Si}$ in diatoms, rivers, and oceans. Paleoceanography 7:739-767

Gargett AE (1991) Physical processes and the maintenance of nutrient-rich euphotic zones. Limnol Oceanogr 36: $1527-1545$

Gibson CH (2000) Laboratory and ocean studies of phytoplankton response to fossil turbulence. Dyn Atmos Oceans 31:295-306

Grover JP (1989) Effect of Si:P supply ratio, supply variability, and selective grazing in the plankton: an experiment with a natural algal and protistan assemblage. Limnol Oceanogr 34:349-367

Grover JP (1991) Resource competition in a variable environment: phytoplankton growing according to the variable-internal-stores model. Am Nat 138:811-835

Grzebyk D, Schofield O, Vetriani C, Falkowski PG (2003) The mesozoic radiation of eukaryotic algae: The portable plastid hypothesis. J Phycol 39:259-267

Hamm CE, Merkel R, Springer O, Jurkojc P, Maier C, Prechtel K, Smetacek V (2003) Architecture and material properties of diatom shells provide effective mechanical protection. Nature 421:841-843

Haq BU, Hardenbol J, Vail PR (1987a) Chronology of fluctuating sea levels during the Mesozoic. Hist Biol 4:75-106

Haq BU, Hardenbol J, Vail PR (1987b) Chronology of fluctuating sea levels since the Triassic. Science 235:1156-1167

Haq BU, Hardenbol J, Vail PR (1988) Mesozoic and Cenozoic chronostratigraphy and cycles of sea-level change. In: Wflgus CK, Hastings BS, Kendali CGSC, Posamentier HW, Ross CA, Van Wagoner JC (eds) Sea-level changes: an integrated approach, Vol 42. Society of Economic Paleontologists and Mineralogists, Knoxville, TN, p 71-108

Harrison KG (2000) Role of increased marine silica input on paleo- $\mathrm{pCO}_{2}$ levels. Paleoceanography 15:292-298

Harwood DM, Nikolaev VA (1995) Cretaceous diatoms: morphology, taxonomy, biostratigraphy. In: Blome C, Whalen P, Reed K (eds) Siliceous microfossils, Vol 8. The Paleontological Society, Tulsa, OK, p 81-106

Henriksson AS (2000) Coccolithophore response to oceanographic changes in the equatorial Atlantic during the last 200,000 years. Paleogeogr Paleoclimatol Paleoecol 156: $161-173$

Holligan PM, Robertson JE (1996) Significance of ocean carbonate budgets for the global carbon cycle. Global Change Biol 2:85-95

Huber BT, Hodell DA, Hamilton CP (1995) Middle-late Cretaceous climate of the southern high latitudes: stable isotopic evidence for minimal equator-to-pole thermal gradients. Geol Soc America Bulletin 107:1164-1191

Hulburt EM (1970) Competition for nutrients by marine phytoplankton in oceanic, coastal, and estuarine regions. Ecology 51:475-484

Hutchinson GE (1961) The paradox of the plankton. Am Nat 95:137-145

Iglesias-Rodriguez DM, Brown CW, Doney SC, Kleypas JA, Kolber D, Kolber Z, Hayes PK, Falkowski PG (2002) Representing key phytoplankton functional groups in ocean carbon cycle models: Coccolithophorids. Global Biogeochem Cycles 16 doi10.1029/2001GB001454

Katz ME, Finkel ZV, Grzebyk D, Knoll AH, Falkowski PG (2004) Evolutionary trajectories and biogeochemical impacts of marine eukaryotic phytoplankton. Annu Rev Ecol Systematics (in press)
Kolmogorov AN (1941) Dissipation of energy in a locally isotropic turbulence. Dokl Akad Nauk SSSR 32:141

Legendre P, Fortin MJ (1989) Spatial pattern and ecological analysis. Vegetatio 80:107-138

Lewis MR, Horne EPW, Cullen JJ, Oakey NS, Platt T (1984) Turbulent mixing may control photosynthesis in the upper ocean. Nature 311:49-50

Li WKW (2002) Macroecological patterns of phytoplankton in the northwestern North Atlantic Ocean. Nature 419: $154-157$

Longhurst AR, Harrison WC (1989) The biological pump: profiles of plankton production and consumption in the upper ocean. Prog Oceanogr 22:47-123

MacArthur RH, Connel JH (1966) The biology of population. John Wiley, New York

Margalef R (1978) Life-forms of phytoplankton as survival alternatives in an unstable environment. Oceanol Acta 1: 493-509

Margalef R (1997) Our biosphere. In: Kinne O (ed) Excellence in ecology, Book 10. International Ecology Institute, Oldendorf/Luhe

Milligan A, Morel FMM (2002) A proton buffering role for silica in diatoms. Science 297:1848-1850

Nance RD, Worsley TR, Moody JB (1988) The supercontinent cycle. Sci Am 259(1):72-79

Quigg A, Finkel ZV, Irwin AJ, Rosenthal Y and 5 others (2003) Plastid inheritance of elemental stoichiometry in phytoplankton and its imprint on the geological record. Nature 425:291-294

Rampino M, Stothers RB (1988) Flood basalt volcanism during the past 250 million years. Science 241:663-668

Raven JA (1997) The vacuole: a cost-benefit analysis. Adv Bot Res 25:59-86

Riegman R, Stolte W, Noordeloos AAM, Slezak D (2000) Nutrient uptake and alkaline phosphatase (EC 3:1:3:1) activity of Emiliania huxleyi (Prymnesiophyceae) during growth under $\mathrm{N}$ and $\mathrm{P}$ limitation in continuous cultures. J Phycol 36:87-96

Roth PH (1987) Mesozoic calcareous nannofossil evolution: relation to paleoceanographic events. Paleoceanography 2:601-612

Sakshaug E, Demers S, Yentsch CM (1987) Thalassiosira oceanica and T. pseudonana: two different photoadaptational responses. Mar Ecol Prog Ser 41:275-282

Siegel DA (1998) Resource competition in a discrete environment: why are plankton distributions paradoxical? Limnol Oceanogr 43:1133-1146

Smetacek V (1999) Diatoms and the ocean carbon cycle. Protist 150:25-32

Smetacek V (2001) A watery arms race. Nature 411:745

Sommer U (1984) The paradox of the plankton: fluctuations of phosphorus availability maintain diversity of phytoplankton in flow-through cultures. Limnol Oceanogr 29: 633-636

Sommer U (1985) Comparison between steady state and non-steady state competition: experiments with natural phytoplankton. Limnol Oceanogr 30:335-346

Sousa WP (1979a) Disturbance in marine intertidal boulder fields: the non-equilibrium maintenance of species diversity. Ecology 60:1225-1239

Sousa WP (1979b) Experimental investigation of disturbance and ecological succession in a rocky intertidal algal community. Ecol Monogr 49:227-254

Spencer-Cervato CT (1999) The Cenozoic deep sea microfossil record: explorations of the DSDP/ODP sample set using the neptune database. Palaeontol Electronica 2: $1-270$ 
Spijkerman E, Coesel PFM (1996) Competition for phosphorus among planktonic desmid species in continuous-flow culture. J Phycol 32:939-948

Thomas WH, Tynan CT, Gibson CH (1997) Turbulence-phytoplankton interrelationship. Prog Phycol Res 12:283-324

Tilman D (1977) Resource competition between plankton algae: an experimental and theoretical approach. Ecology 58:338-348

Turpin DH, Harrison PJ (1979) Limiting nutrient patchiness and its role in phytoplankton ecology. J Exp Mar Biol Ecol 39:151-166

Editorial responsibility: Fereidoun Rassoulzadegan (Contributing Editor), Villefranche-sur-Mer, France
Tyrrell T, Taylor AH (1995) A modelling study of Emiliania huxleyi in the NE Atlantic. J Mar Syst 9:83-112

Watabe N, Wilburn KM (1966) Effects of temperature on growth, calcification, and coccolith form in Coccolithus huxleyi (Coccolithineae). Limnol Oceanogr 11:567-575

Worsley TR, Moody JB, Damian NR (1986) Tectonic cycles and the history of the earth's biochemical and paleoceanographic record. Paleoceanography 1:233-263

Young JR, Didymus S, Mann S (1991) On the reported presence of vaterite and aragonite in coccoliths of Emiliania huxleyi. Bot Mar 34:589-591

Submitted: November 19, 2003; Accepted: January 13, 2004

Proofs received from author(s): May 26, 2004 